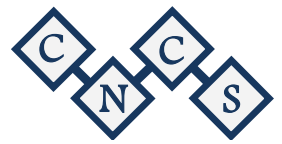

\title{
The Development of Trend Analysis of Scoring for Good Corporate Governance based on the Decree of the Ministry of State Owned Enterprises Number SK-16/S.MBU/2012 in State Owned Banks that Went Public in the Period 2013-2018
}

\author{
Dian Indri Purnamasari ${ }^{1}$ and Hari Kusuma Satria Negara ${ }^{2}$ \\ 1,2 Universitas Pembangunan Nasional "Veteran" Yogyakarta - Indonesia
}

\begin{abstract}
The aims of this research is to evaluate the development of Trend Analysis of Good Corporate Governance Scoring based on the Decree of the Ministry of State Owned Enterprises Number SK-16/S.MBU/2012 in SOEs that went public in the next period of the earlier study in 2012, i.e. 2013-2018 (the latest financial statement at the moment). In this study we employed a population sample of SOEs in banking sector that are listed in BEI for the period 2012-2018. Therefore, this period of study is expected to reflect the actual condition on a more consistent basis from year to year. Publicly traded SOEs are selected because every company that has made public offering is required to publish its annual report in order to make its Annual Report more accessible. We can conclude that the development of scoring for Good Corporate Governance-based on the Decree of the Ministry of State Owned Enterprises Number SK16/S.MBU/2012 in State Owned Banks that went public in the period 2013-2018 - follows an upward trend that put them into the Excellent category.
\end{abstract}

Keywords: Corporate Governance, Banking, Trend Analysis, Scoring, Financial Statement.

\section{INTRODUCTION}

Many people opine that the implementation of Good Corporate Governance (GCG) is indispensable as a barometer for corporate responsibility. Poor implementation of corporate governance $(\mathrm{CG})$ is believed to trigger various corporate financial scandals. GCG implementation is expected to improve company image, to protect stakeholders and to increase compliance to applicable laws and regulations as well as to general business ethics [1].

Cadbury Commitee, as cited in Forum for Corporate Governance in Indonesia (FCGI), defines GCG as "A set of rules that define the relationship between shareholders, managers, creditors, the government, employees and internal and external stakeholders in respect to their rights and responsibilities." To put it simply, GCG is a system that regulates and controls the company. $\mathrm{CG}$ is a set of rules and procedures that guarantee managers to implement ethical management principles.

The government is highly supportive of good governance systems, especially those implemented in their entities, both central and local. The government, as represented by the Ministry of State Owned Enterprises in the Ministerial Decree No. Per-01/MBU/2011 concerning the Implementation of Good Corporate Governance in SOEs, defines GCG as the principles that underlie a company's management process and mechanism based on laws and regulations and business ethics. The government has initiated the implementation of GCG more than a decade ago. In early 2003, by the issuance of the Decree of the Ministry of SOE No. 117/M-MBU/2002 in July 31, 2002, 10 SOEs that have been selected for pilot project of GCG implementation declared a shared commitment to the implementation of GCG principles.

From the description above, we can conclude that GCG implementation in Indonesia underwent several improvements in SOEs, especially those that have gone public. Addendum to the Decree of the Ministry of SOE Number Per-01/MBU/2011 concerning the Implementation of Good Corporate Governance in SOEs, and the Decision of Minister Secretary of SOEs Number SK-16/S.MBU/2012 concerning Indicators/Parameters for Assessment and Evaluation of Good Corporate Governance 
Implementation in SOEs, have enriched the guidelines for the GCG implementation in SOEs.

The study on Scoring of SOEs that went public for the first time since the enactment of the Decree of the Ministry of State Owned Enterprises Number SK-16/S.MBU/2012, revealed that the CG scoring for publicly traded SOEs indicated that out of 19 enterprises, 1 scored excellent, 9 scored very good, 4 scored fair, and 5 scored poor [2]. The scores were based on 153 indicator items with reference to the annual financial statements of each SOE. From this, the present study aims to evaluate the development of Trend Scoring Analysis of Good Corporate Governance based on the Decree of the Ministry of SOEs Number SK16/S.MBU/2012 in SOEs that went public in the next period, i.e. 2013-2018.

The urgency of this study lies in the continuity of scoring of Good Corporate Governance based on the Decree of the Ministry of State Owned Enterprises Number SK-16/S.MBU/2012 by which the scores of the publicly traded SOEs are expected to improve from year to year, which means that the GCG implementation is going to be even better. For that reason, the present study aims to evaluate the development of Trend Analysis of Good Corporate Governance Scoring based on the Decree of the Ministry of State Owned Enterprises Number SK-16/S.MBU/2012 in SOEs that went public in the next period of the earlier study in 2012, i.e. 2013-2018 (the latest financial statement at the moment). This research want to know how the development of Trend Scoring Analysis of Good Corporate Governance based on the Decree of the Ministry of State Owned Enterprises Number SK-16/S.MBU/2012 proceeds among SOEs that went public in the period 2013-2018?

\section{LITERATURE REVIEW AND HYPOTHESIS DEVELOPMENT}

The Law No. 19 of 2003 concerning State Owned Enterprises stipulates that SOE is a business entity that is wholly or partly owned by the central government through a direct participation from separated state assets. Capital participation of government in the establishment of SOEs comes from state budget, capital reserve and other sources.

Good Corporate Governance (GCG)

The term GCG was first introduced by the Cadbury Committee in 1992 as it was used in their report (Cadbury Report). According to the Cadbury Committee, Good Corporate Governance is a set of rules that define the relationship between shareholders, managers, creditors, the government, employees and internal and external stakeholders in respect to their rights and responsibilities. GCG also regulates the relationship between the company and internal and external organs in order to ensure transparency, fairness, responsibility and accountability.

Forum for Corporate Goevernance in Indonesia (2000), in Emirzon (2007), defines CG as a set of rules that define the relationship between shareholders, managers, creditors, the government, employees and internal and external stakeholders in respect to their rights and responsibilities. World Bank defines CG as a set of rules, laws and principles that companies shall comply with in order to ensure the efficient performance of company resources. $\mathrm{CG}$ is, therefore, serves an important role in improving company value on a sustainable basis and in bringing benefits to the relevant shareholders and stakeholders.

GCG implementation can theoretically increase the value of companies by improving their financial performance, reducing the risks that may arise from self-interest in board of commissioners' decision-making, and increasing the number of investors [3]. Article 44 of the regulation of the Ministry of SOEs Number 01 of 2011 stipulates that SOEs are obliged to measure the quality of GCG implementation biennially in the forms of assessment of GCG implementation and evaluation of follow-up on the recommended improvements of earlier assessment results. In principle, the evaluation is performed by SOE itself and the assessment is performed by independent and qualified appraisers that shall be appointed by the Board of Commissioners.

The legal bases for independent assessment of Corporate Governance Implementation in SOEs are: articles 44 (1b), 5),6), (7), and (9) of the Regulation of the Ministry of SOEs Number Per01/MBU/2011 concerning Good Corporate Governance (GCG) implementation in SOEs; and the Decree of the Secretary to the Ministry of SOEs Number SK-16/S.MBU/2012 concerning Indicators/Parameters for Assessment and Evaluation of Good Corporate Governance Implementation in SOEs.

The assessment is intended to determine whether the infrastructures and corporate governance practices comply with the criteria set by the Ministry of SOEs; to identify areas of improvement; to monitor the consistency of GCG implementation in SOEs; and to formulate the necessary corrective and refinement measures. The assessment was conducted by comparing the condition of GCG implementation in each SOE (based on reviews of documents, questionnaires, interviews and observations) and the criteria set by 
D. I. Purnamasari and H. K. Satria Negara / International Journal of Computer Networks and Communications Security, 8 (2), February 2020

the Ministry of SOEs and BPKP consisting of 6 aspects, 43 indicators and 13 parameters. The results consist of scores and their classification, and areas of improvement.

\section{HYPOTHESIS DEVELOPMENT}

The study on Scoring of SOEs that went public for the first time since the enactment of the Decree of the Ministry of State Owned Enterprises Number SK-16/S.MBU/2012, described that there were 19 publicly traded SOEs consisting of 7 enterprises in service, 4 enterprises in banking, and 8 enterprises in manufacturing sectors [2]. The scoring of CG for publicly traded SOEs indicated that out of 19 enterprises, 1 scored excellent, 9 scored very good, and 4 scored fair, and 5 scored poor. The scores were based on 153 indicator items with reference to the annual financial statements of each SOE.
By the enactment of the Decree of the Ministry of SOEs, it is expected that SOEs can implement and independently assess the adequacy of GCG implementation in their companies. Also, based on the parameters and scores, SOEs can perform evaluation of GCG implementation to make it easier for the board of directors to improve performance that, in the end, will increase the company value. From the description above, we formulate the following hypothesis:

$\mathrm{Ha}$ : The development of Trend Scoring Analysis of Good Corporate Governance based on the Decree of the Ministry of SOEs Number SK16/S.MBU/2012 in SOEs that went public in the period 2013-2018 tends to increase.

\section{Theoretical Framework}

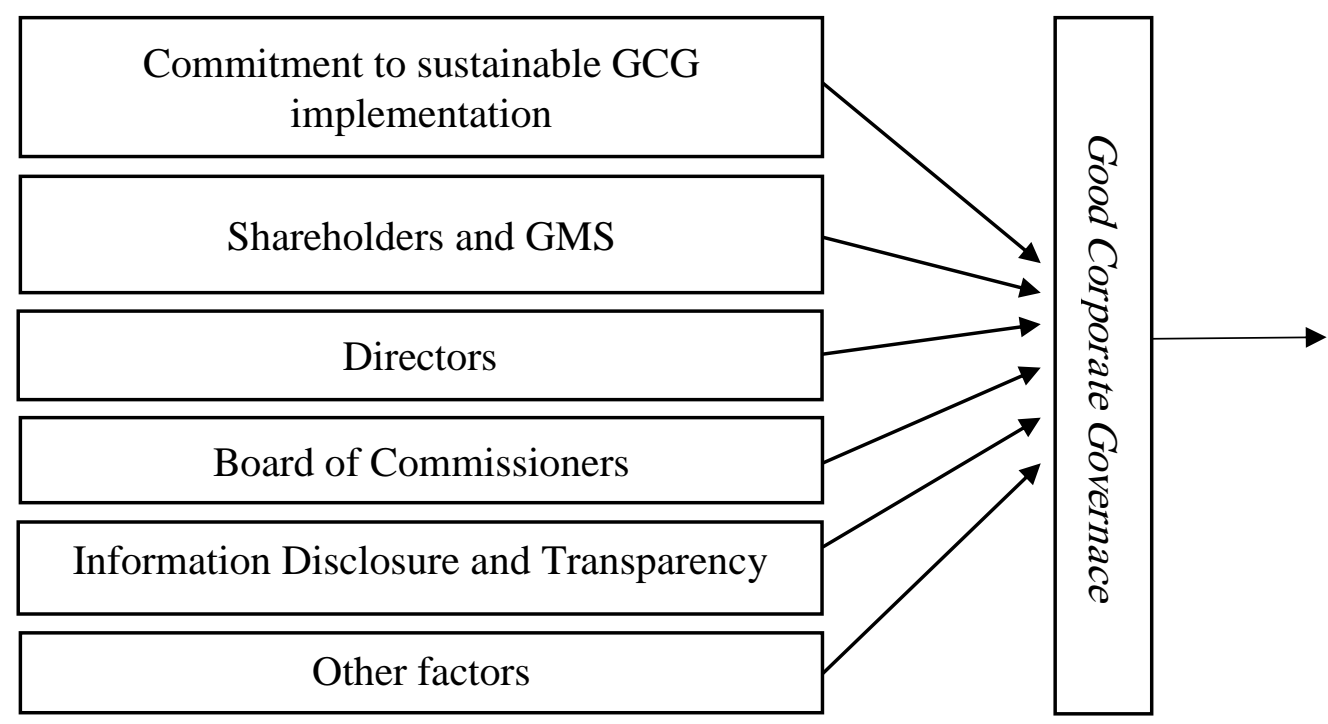

SK BUMN

No.16 Tahun

2013-2018

Fig. 1. Theoretical Framework 
D. I. Purnamasari and H. K. Satria Negara / International Journal of Computer Networks and Communications Security, 8 (2), February 2020

\section{RESEARCH METHODOLOGY}

We choose SOEs as our research population for the reason that they tend to be less prepared for the dynamic business environment-they faced no business competition and, consequently, their efficiency and performance levels are minimum. Therefore, GCG implementation has not been included in their objectives. SOEs become our object of study following the issuance of the Decree of the Ministry of SOEs No Per01/MBU/2011 concerning Good Corporate Governance Implementation in SOEs and of the Decree of Secretary to the Ministry of SOEs No. SK-16/S.MBU/2012 concerning Indicators/Parameters for Assessment and Evaluation of Good Corporate Governance Implementation in SOEs.

In this study we employed a population sample of SOEs in banking sector that are listed in BEI for the period 2012-2018. The period was taken because it relates to the enactment of the Decree No. 16 of 2012 and to the study conducted by [2] for that period. Therefore, this period of study is expected to reflect the actual condition on a more consistent basis from year to year. Publicly traded SOEs are selected because every company that has made public offering is required to publish its annual report in order to make its Annual Report more accessible.

\section{RESEARCH VARIABLES}

The implementation of GC can be measured using the decree issued by the Ministry of SOEs to support the CG implementation in SOEs in compliance with the Decree of the Secretary to the Ministry of SOEs Number: SK-16/S.MBU/2012 concerning the Indicators or Parameters for Assessment and Evaluation of Good Corporate Governance implementation in SOEs. The decree describes in detail the indicators for the assessment of quality of GC implementation in SOEs as follows:

Table 1: Implemetation of GCG in SOEs

\begin{tabular}{clccc}
\hline \hline No. & \multicolumn{1}{c}{ Aspects of Assessment } & Indicators & Parameters & \multicolumn{2}{c}{ Scores } \\
\hline$(1)$ & \multicolumn{1}{c}{$(2)$} & $(3)$ & $(4)$ & $(5)$ \\
\hline \hline 1. & Commitment to sustainable CG & 6 & 15 & 9 \\
2. & Shareholders and GMS & 6 & 25 & 35 \\
3. & Board of Commissioners/Supervisors & 12 & 44 & 35 \\
4. & Directors & 13 & 52 & 9 \\
5. & Disclosure \& Transparency & 4 & 16 & 5 \\
6. & Other aspects & 2 & 2 & 100 \\
\hline
\end{tabular}

Source: Processed data from SK-16/S.MBU/2012

From Table 1 we see that the assessment of GCG implementation involves 6 aspects: (i) commitment to sustainable GCG which consists of 6 indicators with a total of 15 parameters and total score of 7 ; (ii) shareholders and GMS which consist of 6 indicators with 25 parameters and total score of 9; (iii) board of commissioners/supervisors consisting of 12 indicators with a total of 44 parameters and total score of 35; (iv) directors which consist of 13 indicators and a total of 52 parameters and total score of 35; (v) disclosure and transparency which consist of 4 indicators and a total of 16 parameters and total score of 9; and lastly (vi) other aspects that consist of 2 indicators and a total of 2 parameters and total score of 5. The total achieved quality of GCG implementation in SOEs consist of 6 aspects with 43 indicators as detailed in 153 parameters with a total of 100 points. The indicators were made to improve the quality of GC implementation in SOEs in the hope that in case the scoring remains below expectation, an action plan can be devise to take corrective actions. The results of measurement that comply with the Decree that constitutes self-assessment of SOEs' financial statements and report the results of evaluation of GC implementation biennially are as follows: 
D. I. Purnamasari and H. K. Satria Negara / International Journal of Computer Networks and Communications Security, 8 (2), February 2020

Table 2: Assessment Scores of GCG Implementation in SOEs

\begin{tabular}{ccc}
\hline \hline No. & Score & Classification \\
\hline$(1)$ & $(2)$ & $(3)$ \\
\hline \hline 1. & $>85$ & Excellent \\
2. & $75-85$ & Very Good \\
3. & $60-75$ & Good \\
4. & $50-60$ & Fair \\
5. & $<50$ & Poor \\
\hline \hline
\end{tabular}

Source: Processed data from SK-16/S.MBU/2012

We can see from Table 2 that to meet the Excellent classification SOEs' score must be greater than 85; the score in 75-85 range belongs to a Very Good classification; the score in 60-75 range belongs to Good classification; the score in 50-60 range belongs to Fair classification; and, lastly, the score below or equal to 50 belong to Poor classification, or the lowest of all classifications as stipulated in the Decree of the Ministry of SOEs.

\section{DATA ANALYSIS}

The study analyzed four state-owned banks that went public in the period 2013-2018:

1. PT Bank Mandiri, Tbk (BMRI)

2. PT Bank Negara Indonesia, Tbk (BBNI)

3. PT Bank Tabungan Negara, Tbk (BBTN)

4. PT Bank Rakyat Indonesia, Tbk (BBRI)

Data indicated that the scores for all samples in 2013 fall into Good category, which was somewhat disappointing. This is understandable because that year was the first time the scoring was conducted using indicators that comply with the Decree of the Secretary to the Ministry of SOEs Number SK-16/S.MBU/2012 concerning Indicators and Parameters for Assessment and Evaluation of Good Corporate Governance implementation in SOEs. That was the first year when enterprises were not ready or have not giving priority to achieving the scores for GCG implementation, and possibly perceived the definition of and indicators for GCG assessment differently. However, as years passed and their experience improved in adopting and adapting the scoring, some banks changed themselves for the better, despite the ups and downs of their scores.

The table below contains a summary of scoring for State Owned Banks that went public in the period 2013-2018:
Table 3: Scoring

\begin{tabular}{|l|l|l|l|}
\hline EQUITY & YEAR & SCORE & DESCRIPTION \\
\hline \multirow{5}{*}{ NAME } & & & \\
\hline & 2013 & 68.35 & Good \\
\cline { 2 - 4 } & 2014 & 99.57 & Excellent \\
\cline { 2 - 4 } & 2015 & 99.57 & Excellent \\
\cline { 2 - 4 } & 2016 & 99.57 & Excellent \\
\cline { 2 - 4 } & 2017 & 98.11 & Excellent \\
\cline { 2 - 4 } & 2018 & 98.11 & Excellent \\
\hline \multirow{5}{*}{ BBNI } & 2013 & 68.42 & Good \\
\cline { 2 - 4 } & 2014 & 80.44 & Very Good \\
\cline { 2 - 4 } & 2015 & 77.77 & Very Good \\
\cline { 2 - 4 } & 2016 & 80.79 & Very Good \\
\cline { 2 - 4 } & 2017 & 80.79 & Very Good \\
\cline { 2 - 4 } & 2018 & 83.04 & Very Good \\
\hline \multirow{5}{*}{ BBTN } & 2013 & 67.97 & Good \\
\cline { 2 - 4 } & 2014 & 88.20 & Excellent \\
\cline { 2 - 4 } & 2015 & 93.71 & Excellent \\
\cline { 2 - 4 } & 2016 & 93.34 & Excellent \\
\cline { 2 - 4 } & 2017 & 93.94 & Excellent \\
\cline { 2 - 4 } & 2018 & 94.36 & Excellent \\
\hline \multirow{5}{*}{ BBRI } & 2013 & 61.48 & Good \\
\cline { 2 - 4 } & 2014 & 66.98 & Good \\
\cline { 2 - 4 } & 2015 & 69.19 & Good \\
\cline { 2 - 4 } & 2016 & 69.94 & Good \\
\cline { 2 - 4 } & 2017 & 71.02 & Good \\
\cline { 2 - 4 } & 2018 & 71.30 & Good \\
\hline
\end{tabular}

Source: Processed data from SK-16/S.MBU/2012

Table 3 indicates that in 2013 the score of PT Bank Mandiri, Tbk has increased significantly from 68.35 (Very Good) to 99.57 (Excellent). It scores has been consistent because it remained in Excellent category from 2014 to 2018, despite one (1) score point decrease in 2017-2018. The results in the table can be illustrated in a graphical representation below: 


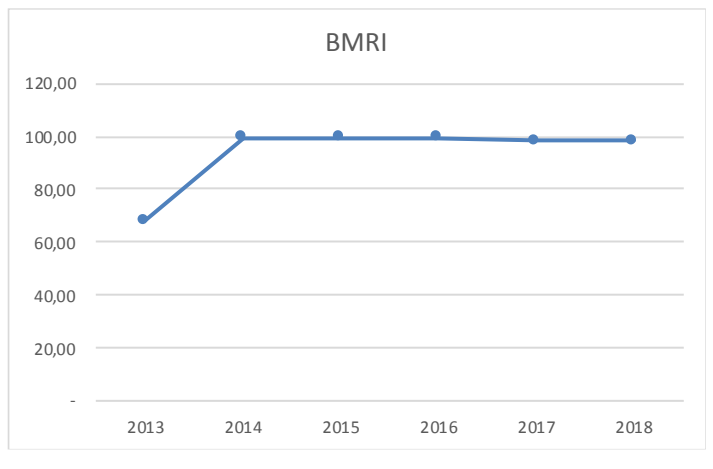

Fig. 2. BMRI Trend

Table 3 indicates that in 2013 the score of PT Bank Negara Indonesia, Tbk has increased from 68.42 (Good) to 80.44 (Very Good). The score has been consistent because the bank remained in a Very Good category from 2014 to 2018, despite its three (3) score point decrease in 2015. The results presented in the table can be illustrated in the following graphical representation:

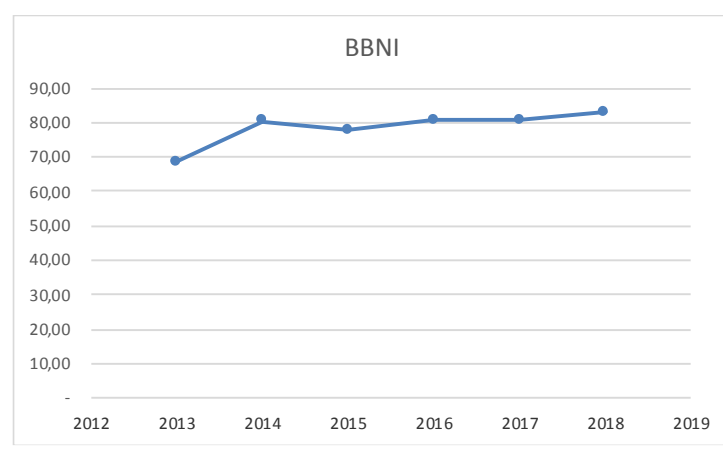

Fig. 3. BBNI Trend

Table 3 indicates that by the year 2013 the score of PT Bank Tabungan Negara, Tbk has significantly increased from 67.97 (Good) to 88.20 (Excellent). The score has increased quite consistently as the bank remained in an Excellent category without any decrease in score point. This reflects the consistency of the bank in maintaining its GCG implementation score. The results are illustrated as the following graphical representation:

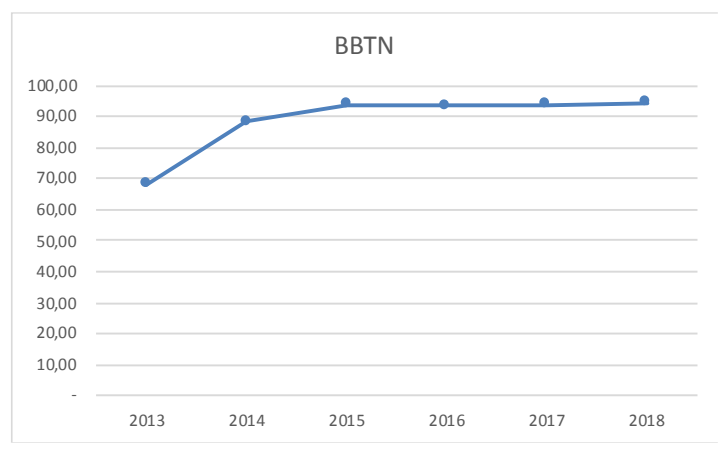

Fig. 4. BBTN Trend

Table 3 indicates that in 2013 the score of PT Bank Rakyat Indonesia, Tbk has increased to 61.48 (Good), yet such an increase has been sluggish as can be seen from the period 2013-2018 where the bank remained in a Good category. This result is illustrated in the following graphical representation:

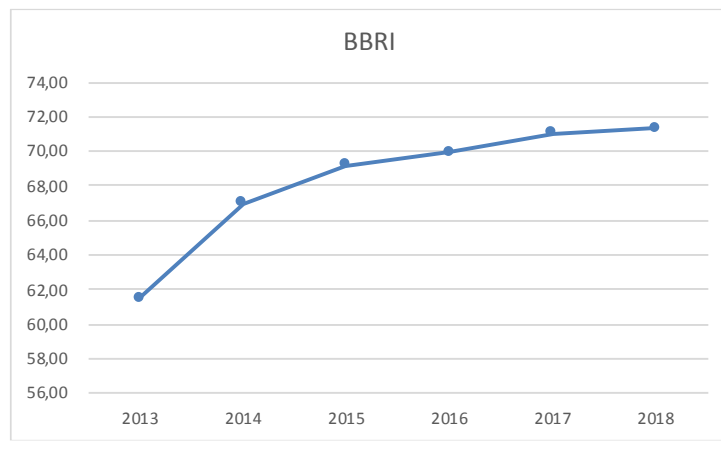

Fig. 5. BBRI Trend

Overall, the results of analysis and scoring indicate that the development of scoring for Good Corporate Governance based on the Decree of the Ministry of State Owned Enterprises Number SK$16 /$ S.MBU/2012 in state owned banks that went public in the period 2013-2018 follows an upward trend or, in other words, it tends to increase. Consistent rates of increase have been found in the scores of PT Bank Mandiri, Tbk and PT Bank Tabungan Negara, Tbk, but this does not mean that the other two have not implement GCG. 
The possible reasons for this might include: (1) differences in perceiving GCG implementation that lead to different definition and wordings of the indicators, and thereby undetected by the scoring system in this study; (2) Differences in market segmentation focus among banks that make it possible to put a priority on GCG implementation that the customers find it easier to understand than the terms in the indicator; and (3) Different wordings of a definition when it is applied in the indicators. The figure below explains the trend analysis of scoring for State Owned Banks for the period 2013-2018 indicating an upward trend.

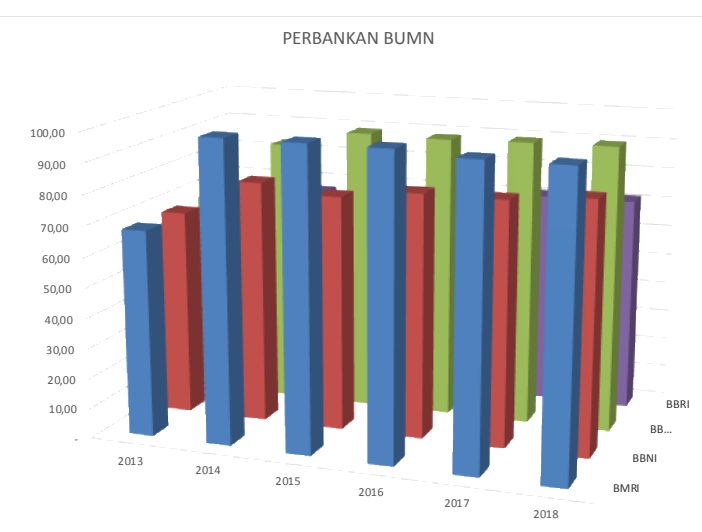

Fig. 6. Graphical Trend Analysis of State Owned Banks

\section{CONCLUSION}

From the results of analysis and scoring presented above, we can conclude that the development of scoring for Good Corporate Governance - based on the Decree of the Ministry of State Owned Enterprises Number SK16/S.MBU/2012 in State Owned Banks that went public in the period 2013-2018-follows an upward trend that put them into the Excellent category.

The findings of the current research are expected to further encourage State Owned Banks in implementing GCG in their companies. They also have several significant implications for SOEs, particularly those that went public, in addition to serving as indicators for the scoring of GCG implementation in all entities intended to go public.

We plan to conduct further study in the future to monitor the consistency of GCG implementation and, at the same time, to compare the SOEs studied with those in other sectors, or with private banks.

\section{REFERENCES}

[1] Fitriyani, Dewi; Tiswiyanti, Wiwik ; Prasetyo, Eko . 2015. Praktik Good Corporate Governance dan Dampaknya Terhadap Kinerja Berdasarkan Balanced Scorecard Pada Perusahaan Daerah Air Minum. Makalah dipresentasikan di Conference in Business, Accounting, and Management 2. Universitas Islam Sultan Agung. Semarang

[2] Purnamasari, Dian Indri, Rahmawati, dan Mulyanto. 2016. Differences in Budgetary Participation in View Of Assessment of Corporate Governance, Sector, and the Experience of Managers in Public SOE in Indonesia.INFORMATION-An International Interdisciplinary Journal, Vol. 19, No. 7(A), July, 2527-2532.

[3] Iskan, Dahlan. 2012. Dahlan Akui Rancangan Anggaran BUMN Copy Paste, 29 Mare http://www.republika.co.id/berita/ekonomi/ma kro/12/03/28/m1lpda-dahkan-akui-praktikcopy-paste-dalam-anggaran-bumn.

\section{Government Policy}

[4] Kementerian BUMN. 2002. Penerapan Praktek Good Corporate Governance Pada Badan Usaha Milik Negara (BUMN). Keputusan Menteri No. Kep-117/M- MBU/2002. Jakarta: BUMN.

[5] Kementerian BUMN. 2006. Komite Audit bagi BUMN. Peraturan Menteri No. PER05/MBU/2006. Jakarta: BUMN.

[6] Kementerian BUMN. 2011. Penerapan Tata Kelola Perusahaan yang Baik (Good Corporate Governance). Peraturan Menteri No. PER01/MBU/2011. Jakarta: BUMN.

[7] Kementerian BUMN. 2012. Indikator/Parameter Penilaian dan Evaluasi atas Penerapan Tata Kelola Perusahaan yang Baik (Good Corporate Governance) pada Badan Usaha Milik Negara. Keputusan Menteri No. SK16/S.MBU/ 2012. Jakarta: BUMN. 